\title{
Effect of Crop Geometry and Nutrient Management in Barnyard Millet under Sodic Soil Condition
}

\author{
S. Anandha Krishnaveni* and S. Avudaithai \\ AnbilDharmalingam Agricultural College and Research Institute, \\ Navalurkuttapattu, Tiruchirapalli-620 027, India \\ *Corresponding author
}

\section{A B S T R A C T}

\section{Keywords}

Crop geometry, nutrient requirement, barnyard millet, sodic soil

\section{Article Info}

Accepted:

14 May 2020

Available Online:

10 June 2020
The field experiments were conducted with an objective to study the impact of spacing on the productivity and to optimize the nutrient requirement for barnyard millet (Kudiraivali) under sodic soil condition using the short duration high yielding variety Co $(\mathrm{KV})_{2}$ during summer season of 2018 and 2019 at Anbil Dharma lingam Agricultural College and Research Institute, Trichy. The experiments were carried out in FRBD comprising two factors viz., crop geometry and nutrient management. Factor one consist of $S_{1}-20 \times 10 \mathrm{~cm}, S_{2}-15 \times 10 \mathrm{~cm}$ and $S_{3}-25 \times 10 \mathrm{~cm}$. Nutrient management practices like $\mathrm{N}_{1}-100 \% \mathrm{~N}+100 \% \mathrm{P}$, $\mathrm{N}_{2}-100 \% \mathrm{~N}+100 \% \mathrm{P}+\mathrm{FYM} @ 12.5 \mathrm{t} / \mathrm{ha}, \mathrm{N}_{3}-125 \% \mathrm{~N}+125 \% \mathrm{P}$ and $\mathrm{N}_{4}-125$ $\% \mathrm{~N}+125 \% \mathrm{P}+\mathrm{FYM} @ 12.5 \mathrm{t} / \mathrm{ha}$. The experiment was replicated thrice. Totally twelve treatment combinations were analyzed. Results revealed that spacing at $15 \times 10 \mathrm{~cm}$ with $125 \% \mathrm{RDF}$ of $\mathrm{N}+\mathrm{P}$ along with FYM recorded highest grain yield of $608 \mathrm{~kg} / \mathrm{ha}$ with increased growth parameters like plant height, number of tillers and yield attributes viz., number of panicles, length of panicle and weight of the panicle.

\section{Introduction}

In recent years, there has been increasing recognition of the importance of millets as a substitute for major cereal crops. Millets have the potentiality of contributing to increased food production both in developing and developed countries Sahu (1965).In India Kudiraivali is an important dry land crop and cultivated over a wide array of environmental conditions even under poor soil conditions. It has the special feature of drought resistance and can withstand water logging up to 2 weeks. It has field duration of 70-90 days. Due to its quick growth, it can be grown as a short-term catch crop.

It is used as reclamation crops on land that is too saline for rice. It is the very quickest crop among all millets. It is equally important as a 
grain and fodder crop. Thus it deserves a greater importance than other millets. However, in reality the potentiality of this crop is not fully exploited.

One of the major reasons for low productivity of crops grown in salt-affected soil is the salt toxicity and poor soil properties (Gao et al., 2008). In India, 3.79 million ha and 0.35 million ha in Tamil Nadu have been affected by sodicity which affects productivity of the land directly. Soil sodicity is characterized by high $\mathrm{pH}$, high water soluble and exchangeable sodium and low biological activity. As a result, these soils exhibit poor physical properties often leading to low water conductivity at the surface and transmission within the profile besides, being deficient in many essential nutrients (Ghafoor et al., 2008).

The lower crop productivity is mainly due to poor crop management practices such as inadequate planting density and nutrition, high weed infestation, incidence of disease and insect pests. Crop geometry is the area occupied by the individual plant. It decides the number of plants per unit area. The plant population at the time of harvest decides the yield of any crop.

Optimum population level is the one, which provides the plant with the best environment to express its capacity fully under the given conditions. Intra and inter row spacing is one of the important components of systematic cultivation and manipulation, that could enhance productivity of this important crop. Due to proper spacing plant can gain sufficient sunlight, water and nutrition from soil, which can influence healthy yield and yield attributes. Therefore, there is a need to understand the relationship between crop geometry and nutrient requirement with yield. Hence, the experiments were carried out with an objectives to find out the suitable spacing and to optimize the nutrient requirement for barnyard millet (kudiraivali) undersodic soil condition.

\section{Materials and Methods}

Field experiments were conducted at AnbilDharmalingam Agricultural College and Research Institute with an objective to find out the suitable crop geometry and to optimize the nutrient requirement for barnyard millet (Kudiraivali) under sodic soil condition using the short duration high yielding variety $\mathrm{Co}(\mathrm{KV})_{2}$ during summer season of 2018 \&2019. The experiment was carried out in FRBD and replicated thrice. Treatment comprising two factors as follows.

\section{Factor 1 (Spacing)}

$\mathrm{S}_{1}-20 \times 10 \mathrm{~cm}$

$\mathrm{S}_{2}-15 \times 10 \mathrm{~cm}$

$\mathrm{S}_{3}-25 \times 10 \mathrm{~cm}$

\section{Factor 2 (Nutrient management)}

$$
\begin{aligned}
& \mathrm{N}_{1}-100 \% \mathrm{~N}+100 \% \mathrm{P} \text { (as per CPG) } \\
& \mathrm{N}_{2}-100 \% \mathrm{~N}+100 \% \mathrm{P}+\mathrm{FYM} 12.5 \mathrm{t} / \mathrm{ha} \\
& \mathrm{N}_{3}-125 \% \mathrm{~N}+125 \% \mathrm{P} \\
& \mathrm{N}_{4}-125 \% \mathrm{~N}+125 \% \mathrm{P}+\mathrm{FYM} @ 12.5 \mathrm{t} / \mathrm{ha} \\
& * * 100 \% \quad-\text { Nitrogen is } 44 \mathrm{~kg} / \mathrm{ha} \text { and } \\
& \text { Phosphorous } 22 \mathrm{~kg} / \mathrm{ha}
\end{aligned}
$$

Kudiraivali variety $\mathrm{Co}(\mathrm{KV}) 2$ comes to harvest at 90 days. Totally twelve treatment combinations were tried. Biometric observations were recorded at various growth stages. At establishment stage plant population $/ \mathrm{m}^{2}$ was taken.

The growth parameters like plant height and number of tillers were recorded. At harvest stage the yield attributes viz., number of panicles/hill, length of the panicle and grain yield were recorded. All the collected data were statistically analyzed. 


\section{Results and Discussion}

The effect of crop geometry and nutrient management practices on growth parameters and yield attributes are presented in Table 1 and table 2 , respectively.

\section{Growth parameters}

\section{Plant population}

Among the various spacing adopted, $\mathrm{S}_{2}$ (15 $\mathrm{x} 10 \mathrm{~cm})$ significantly recorded the highest plant population than other treatments. There is no significant difference found with regard to nutrient levels.

\section{Plant height}

With regard to factor 1, spacing @ $15 \times 10 \mathrm{~cm}$ significantly recorded the highest plant of $106.2 \mathrm{~cm}$ followed by spacing @ $20 \times 10 \mathrm{~cm}$. Similarly with respect to nutrient management factor $\mathrm{N}_{4}$ significantly recorded the highest plant of $104.2 \mathrm{~cm}$ followed by $\mathrm{N}_{3}$ which is on par with $\mathrm{N}_{2}$. There is no interaction effect

\section{No. of tillers per plant}

In Factor 1 spacing $S_{3} @ 25 \times 10 \mathrm{~cm}$ recorded 5 numbers of tillers per plant. It is on par with other spacing. They are non- significant. In second factor, $\mathrm{N}_{4}$ recorded 5 no of tillers per plant. There is no significant difference was found and. There is no interaction effect

However, there is no significant difference in the growth parameters viz., plant height and number of tillers. Intra and inter row spacing is one of the important components of systematic cultivation and manipulation, that could enhance productivity of the crop.

The increase in all growth parameters might be due to sufficient availability of sunlight, water and nutrition from soil to each crop under proper spacing. These findings are supported by the findings of Kole (2010) and Avasthe et al., (2012).

\section{Yield attributes and yield}

\section{No. of panicles per plant}

There is no significant difference found with regard to no. of panicles per plant inthe factors viz., different spacing and nutrient management. The interaction between spacing and nutrient management is not significant.

\section{Panicle length $(\mathrm{cm})$}

With regard to panicle length there is no significant difference found in both spacing and nutrient management factors.

\section{Panicle weight (g)}

Spacing @15 x10 cm significantly recorded the highest panicle weight of $4.75 \mathrm{~g}$ followed by spacing @20x10 cm. Similarly with respect to nutrient management factor $\mathrm{N}_{4}$ significantly recorded the highest panicle weight followed by $\mathrm{N}_{3} \& \mathrm{~N}_{2}$. There is no interaction effect.

\section{Grain yield}

The highest grain yield of $593 \mathrm{~kg} / \mathrm{ha}$ was recorded by the spacing $\mathrm{S}_{2} @ 15 \times 10 \mathrm{~cm}$ followed by the spacing @20 x10 cm. There is a significant difference in the grain yield among the treatments.

This might be due to more population of plants by close spacing and hence more yield per hectare. With respect to nutrient management $\mathrm{N}_{4}-125 \% \mathrm{~N}+125 \% \mathrm{P}+$ FYM@ $12.5 \mathrm{t} / \mathrm{ha}$ significantly recorded the highest grain yield of $608 \mathrm{Kg} / \mathrm{ha}$ followed by $\mathrm{N}_{3} \& \mathrm{~N}_{2}$. 
Table.1 Effect of crop geometry and nutrient management on Growth parameters

\begin{tabular}{|c|c|c|c|}
\hline Treatments & $\begin{array}{c}\text { Plant } \\
\text { Population }\left(\mathbf{m}^{2}\right)\end{array}$ & $\begin{array}{l}\text { Plant height } \\
\text { (cm) }\end{array}$ & $\begin{array}{c}\text { No of } \\
\text { tillers/plant }\end{array}$ \\
\hline \multicolumn{4}{|l|}{ Factor 1 (Spacing) } \\
\hline$S_{1}-20 \times 10 \mathrm{~cm}$ & 29 & 98.3 & 4 \\
\hline$S_{2}-15 \times 10 \mathrm{~cm}$ & 35 & 106.2 & 4 \\
\hline$S_{3^{-}} 25 \times 10 \mathrm{~cm}$ & 23 & 92.0 & 5 \\
\hline SEd & 2 & 1.6 & - \\
\hline CD $(0.05)$ & 5 & 3.4 & NS \\
\hline \multicolumn{4}{|l|}{ Factor 2 (Nutrient management) } \\
\hline$N_{1}-100 \% N+100 \% P \quad$ (as per CPG) & 29 & 93.7 & 4 \\
\hline $\mathrm{N}_{2}-100 \% \mathrm{~N}+100 \% \mathrm{P}+\mathrm{FYM} @ 12.5 \mathrm{t} / \mathrm{ha}$ & 30 & 96.8 & 4 \\
\hline $\mathrm{N}_{3}-125 \% \mathrm{~N}+125 \% \mathrm{P}$ & 29 & 100.5 & 4 \\
\hline $\mathrm{N}_{4}-125 \% \mathrm{~N}+125 \% \mathrm{P}+\mathrm{FYM} @ 12.5 \mathrm{t} / \mathrm{ha}$ & 31 & 104.2 & 5 \\
\hline SEd & - & 1.7 & \\
\hline CD ( 0.05) & NS & 3.9 & NS \\
\hline
\end{tabular}

Table.2 Effect of crop geometry and nutrient management on the Yield attributes and yield

\begin{tabular}{|c|c|c|c|c|}
\hline Treatments & $\begin{array}{c}\text { No. of } \\
\text { panicles / } \\
\text { plant }\end{array}$ & $\begin{array}{c}\text { Panicle } \\
\text { length } \\
\text { (cm) }\end{array}$ & $\begin{array}{c}\text { Panicle } \\
\text { weight } \\
\text { (g) }\end{array}$ & $\begin{array}{c}\text { Grain } \\
\text { Yield } \\
\text { (Kg/ha) }\end{array}$ \\
\hline \multicolumn{5}{|l|}{ Factor 1 (Spacing) } \\
\hline$S_{1}-20 \times 10 \mathrm{~cm}$ & 6 & 16.23 & 4.27 & 517 \\
\hline$S_{2}-15 \times 10 \mathrm{~cm}$ & 7 & 16.82 & 4.75 & 593 \\
\hline$S_{3^{-}} 25 \times 10 \mathrm{~cm}$ & 6 & 15.70 & 3.78 & 365 \\
\hline SEd & - & - & 0.1 & 33 \\
\hline CD $(\mathbf{0 . 0 5})$ & NS & NS & 0.3 & 71 \\
\hline \multicolumn{5}{|l|}{ Factor 2 (Nutrient management) } \\
\hline$N_{1}-100 \% N+100 \% P($ as per $C P G)$ & 5 & 16.01 & 4.01 & 465 \\
\hline $\mathrm{N}_{2}-100 \% \mathrm{~N}+100 \% \mathrm{P}+\mathrm{FYM} @ 12.5 \mathrm{t} / \mathrm{ha}$ & 4 & 16.11 & 4.36 & 472 \\
\hline $\mathrm{N}_{3}-125 \% \mathrm{~N}+125 \% \mathrm{P}$ & 4 & 16.36 & 4.17 & 521 \\
\hline $\mathrm{N}_{4}-125 \% \mathrm{~N}+125 \% \mathrm{P}+\mathrm{FYM} @ 12.5 \mathrm{t} / \mathrm{ha}$ & 5 & 16.56 & 4.74 & 608 \\
\hline SEd & - & - & 0.2 & 36 \\
\hline CD ( 0.05) & NS & NS & 0.5 & 83 \\
\hline
\end{tabular}

This is mainly due to adequate spacing plant can gain sufficient sunlight, water and nutrition from soil, which can influence healthy yield and yield attributes. Khan and Agrawal (1995) reported in ragi that the seed yield was highest with 2, 60,000 plants per hectare. Similar findings were reported by Manjunatha et al., (2010) and Sridhar et al., (2011).
From this study, it is concluded that crop geometry@15 x $10 \mathrm{~cm}$ was found to be the best spacing and $\mathrm{N}_{4}-125 \% \mathrm{~N}+125 \% \mathrm{P}+$ FYM@12.5 t / ha could be adopted as optimum dose of nutrients to get higher grain yield in barnyard millet under sodic soil condition. 


\section{References}

Avasthe, R. K., Verma, S., Ashok Kumar and Rahman, H., 2012. Performance of rice (Oryza sativa) varieties at different spacing under system of rice intensification (SRI) mid hill acid soils of Sikkim Himalaya, Indian J. Agric., 79(1) : 32-37.

Kole, G. S., 2010, Response of baby corn (Zea mays) to plant density and fertilizer levels. M. Sc. (Agri.) Thesis, Univ. Agric. Sci., Dharwad, Karnataka (India).

Manjunatha, M. J., Halepyati, A. S., Koppalkar, B. G. and Pujari, B. T., 2010, Influence of different plant densities on the growth, yield and economics of $\mathrm{Bt}$ cotton (Gossypium hirsutum) varieties under dryland condition. Karnataka J. Agric. Sci., 23(4): 580-583.

Sahu, B. N., 1965, Response of different crops to fertilizer application in different soils. J. Indian Soc. Soil Sci., $13: 241-249$.

Sridhar, C. J., Ramachandrappa, B. K., Kumarswamy, A. S. and Gurumurthy, K. J., 2011. Effect of varieties, planting geometry and methods of establishment on root traits and yield of aerobic rice. Karnataka J. Agric. Sci., 24(2) : 129132.

\section{How to cite this article:}

Anandha Krishnaveni. S. and Avudaithai. S. 2020. Effect of Crop Geometry and Nutrient Management in Barnyard Millet under Sodic Soil Condition. Int.J.Curr.Microbiol.App.Sci. 9(06): 276-280. doi: https://doi.org/10.20546/ijcmas.2020.906.035 